\title{
Braking Process of Sports Motorbike
}

\author{
Piotr Czech ${ }^{1, *}$, Błażej Szyma ${ }^{1}$, Michał Juzek ${ }^{1}$ and Robert Kałuża ${ }^{1}$ \\ ${ }^{1}$ Silesian University of Technology, Faculty of Transport, 40-019 Katowice, 8 Krasinskiego Street, Poland
}

\begin{abstract}
In the event of an emergency, head of the motorcycle has a split second to decide what to do defensive maneuver. The most common choice is the braking maneuver. Starting motorcycle braking is associated with the selection of additional brake, which uses a driver. It is here to choose to use the front brake, rear or both simultaneously. On the course of the braking process will also influence the type of surface on which the vehicle is moving, the smoothness and atmospheric conditions. Undoubtedly, to obtain high values of deceleration may contribute the appropriate tire pressure, or the load on the motorcycle. The tests conducted here show the influence of different factors on the proper functioning of the braking system and at the same time on the delay of the motorbike. Tests were carried out for sports motorbike.
\end{abstract}

Keywords: braking process, braking deceleration, motorbike.

\section{Introduction}

Every day on the roads around the world comes to accidents. Their incidence is affected by a number of factors. These may include factors depending on the person, the vehicle or environment. In an emergency situation, vehicle driver usually tries to avoid an accident by braking maneuver.

The vehicle braking system is designed to reduce the driving speed and stopping in a point specified by the driver. This system is also used to immobilize the vehicle during standstill. Due to active participation in the course of the driving it is classified as the active safety system. The loss of speed is done by braking, which is the process of having a huge impact on road safety. During braking accident forces acting on the vehicle have an opposite sense to the driving direction. This causes a reduction or complete dispersal of previously accumulated kinetic and potential energy of the vehicle. For direct production and changes in forced resistance movement of the vehicle are used devices called braking mechanisms $[1,2,6,7,13$, 15].

The driver of the vehicle is an essential element affecting the safety of the road. The reactions are followed by optical observations. It should be noted that conscious reactions occur when objects are in the area of the sharp vision (observation time), are captured (capture time) and logically processed (information processing time). Then, as a result of impulses by using muscle action will be executed subconscious technical process (adaptation time). Subconscious reactions (programmed) can be worked out by training, reducing the time and the correct running. However, our observations and capture times are the same for most people [10, 11, 14, 17-19].

Braking process of the vehicle consists of several phases. The first phase includes psychomotor time of the driver, and the delay time of the brake. Psychomotor time includes the time of perception, reaction time, and the time 
required by the driver to start the brake lever Psychomotor time is in the range of 0.2 [s] to 1.5 [s], depending on the abilities and skills of the driver. Important factors are also conditions while driving. Start-up time is counted from the moment of appearance the force actuating the brake to the time of deceleration. The impact on this time has technical efficiency of the braking system and the construction characteristics of the vehicle. The second phase includes the rise time of delay. It is measured from the moment of contact between the friction elements to achieve the maximum value of the intended delay. This value depends on the intensity of pressure that the driver exerts on the brake and the waveforms of transient processes in the system. This value depends on the intensity of pressure that the driver exerts on the brake and the waveforms of transient processes in the system. The next phase of braking, includes full braking performance until the vehicle stops. As the start time calculation is assumed the moment of action of the driver to the control system of brakes $[10,11,14,17-19]$.

One of the types of vehicles involved in road accidents are motorcycle.

With the current increase of power and improvement of driving possibilities of motorcycles most important thing is the possibility of quick and safe stop. Currently, the motorcycle vehicles are dominated by the introduction of electronic trend, which is to effectively assist the driver in emergency situations. The main aim of designers is to reduce wheel slippage in this type of vehicles, because they are the ones next to the excessive speed the most common cause of accidents involving motorcyclists.

The value of derived delay in the braking process is used to evaluate the effectiveness of the brakes work. Knowledge of the braking deceleration frequently determines the possibility of a correct assessment of contributing to the road accident which occurred by its participants. Knowledge of this parameter is very important for the forensic experts analyzing traffic accidents $[2,11,15,17,18$, 19].

The article presents the results of studies designed to measure the braking deceleration sports motorcycle. It was examined how the different factors affecting its value.

\section{Description of the research}

The object on which the research was carried out was a Japanese motorcycle Honda CB 600 $F$ version Naked bike, commonly known as the Honda Hornet. It was produced in 2001 (figure 1).

Table 1 summarizes the most important technical data of the motorcycle.

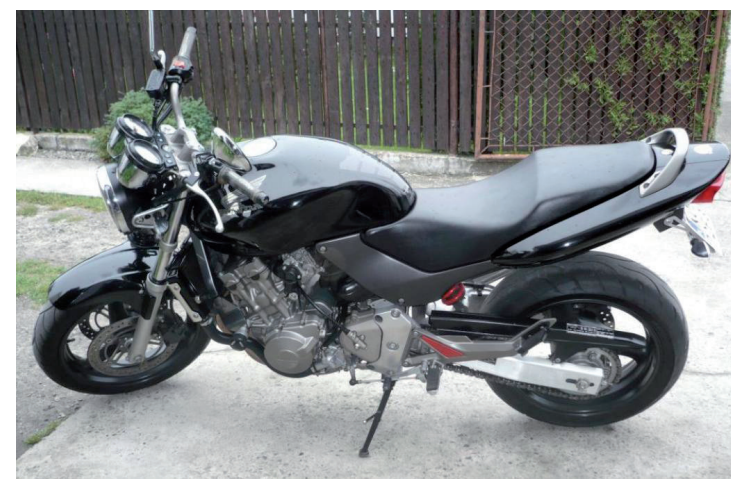

Fig. 1: Honda CB $600 \mathrm{~F}$ (Hornet).

Table 1: Technical data of the Honda CB 600 F (Hornet) motorcycle.

\begin{tabular}{|c|c|}
\hline Engine & $\begin{array}{l}\text { the liquid-cooled, four-stroke, timing } \\
\text { gear: DOHC, } 4 \text { valves per cylinder }\end{array}$ \\
\hline Engine displacement & $599[\mathrm{ccm}]$ \\
\hline $\begin{array}{l}\text { Cylinder diameter } x \\
\text { piston stroke }\end{array}$ & $65 \times 42,5[\mathrm{~mm}]$ \\
\hline Compression ratio & $12,0: 1$ \\
\hline Lubrication & with a wet sump \\
\hline Start-up & electric \\
\hline Clutch & multiple-disk clutch, wet \\
\hline Transmission & Manual, 6-speed \\
\hline Maximum power & $71,1[\mathrm{~kW}]$ at 12000 [rev/min] \\
\hline Maximum torque & $66,5[\mathrm{Nm}]$ at $10000[\mathrm{rev} / \mathrm{min}]$ \\
\hline Final drive ratio & chain O-ring type \\
\hline Front suspension & $\begin{array}{l}41 \mathrm{~mm} \text { telescopic fork with oil } \\
\text { damping, } 125[\mathrm{~mm}] \text { stroke }\end{array}$ \\
\hline Rear suspension & $\begin{array}{l}\text { aluminium swingarm, the central } \\
\text { spring-damping element }\end{array}$ \\
\hline Tires - front & 120/70-ZR17 (61W), 2,5 [bar] \\
\hline Tires - rear & 180/55-ZR17 (73W), 2,9 [bar] \\
\hline Brakes - front & $\begin{array}{l}\text { double disc brakes, } 296 \text { [mm], two- } \\
\text { piston calipers NISSIN }\end{array}$ \\
\hline Brakes - rear & $\begin{array}{l}\text { single disc brake, } 220[\mathrm{~mm}] \text {, single- } \\
\text { piston floating caliper NISSIN }\end{array}$ \\
\hline $\begin{array}{l}\text { Total length } x \text { height } \\
x \text { width }\end{array}$ & $2055 \times 1070 \times 755[\mathrm{~mm}]$ \\
\hline
\end{tabular}




\begin{tabular}{|l|l|}
\hline Wheelbase & $1420[\mathrm{~mm}]$ \\
\hline $\begin{array}{l}\text { The mass of the } \\
\text { motorcycle ready } \\
\text { to ride }\end{array}$ & $198[\mathrm{~kg}]$ \\
\hline Fuel tank capacity & $16\left[\mathrm{dm}^{3}\right]$ \\
\hline Maximum speed & $226,6[\mathrm{~km} / \mathrm{h}]$ \\
\hline
\end{tabular}

Studies were conducted using an METER PRO XL accelerometer. This is a measuring device, recording the instantaneous longitudinal acceleration and a lateral vehicle. Rated data the device is shown in Table 2.

Table 2: Data concerning the measuring device.

\begin{tabular}{|l|l|}
\hline Scope & $\begin{array}{l}-5,0 \ldots+5,0\left[\mathrm{~m} / \mathrm{s}^{2}\right] \text { to } \\
-20,0 \ldots+20,0\left[\mathrm{~m} / \mathrm{s}^{2}\right]\end{array}$ \\
\hline Resolution & $0,0021\left[\mathrm{~m} / \mathrm{s}^{2}\right]$ \\
\hline Measurement frequency & $25[\mathrm{~Hz}]-200[\mathrm{~Hz}]$ \\
\hline Working temperature & $0-50\left[{ }^{\circ} \mathrm{C}\right]$ \\
\hline
\end{tabular}

The measuring device has been installed on the fuel tank on a special rubber pads to soften the vibration during measurement. Then, the device was stuck on a double-sided tape (white elements, under the device in Figure 2) and additionally secured by a black tape from the top (stuck to the tank and the frame elements).

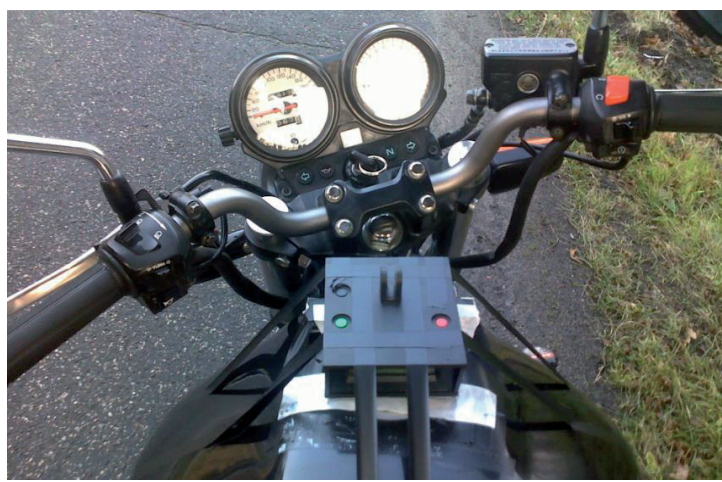

Fig. 2: Method of mounting the measuring device on a motorcycle.

Measurements were carried out to compare one with the braking parameters which is the average total deceleration:

$a_{m}=\frac{V_{b}^{2}-V_{e}^{2}}{25,92 \cdot\left(S_{e}-S_{b}\right)}\left[\mathrm{m} / \mathrm{s}^{2}\right]$ where: $V_{b}$ - vehicle speed corresponding to the initial speed of 0,8 $\left(V_{1}\right)[\mathrm{km} / \mathrm{h}] ; V_{e}-$ vehicle speed corresponding to the initial speed of $0,1\left(V_{1}\right)$ $[\mathrm{km} / \mathrm{h}] ; S_{b}$ - distance traveled between $V_{1}$ and $V_{b}$ [m]; $S_{e}$ - distance traveled between $V_{1}$ and $V_{b}$ [m].

The formula for the mean fully developed deceleration is an model auxiliary, because the value of this parameter can be read directly from the measurement device after carried out a series of measurements Using the supplied software can be synchronized all attempts and send them from device to your computer. This makes it possible to observe any changes during braking on a computer monitor.

Research on braking deceleration of the motorcycle were carried out on different road surfaces:

$\checkmark$ asphalt surface, an apparent porosity, $\operatorname{dry}(A)$,

$\checkmark$ gravel surface, dry (B),

$\checkmark$ asphalt surface, smooth, dry (C1),

$\checkmark$ asphalt surface, smooth, wet (C2).

In order to compare the measurements made during the braking of the motorcycle on different road surfaces, as a result of the maximum delay has been adopted the best result from the series - as $100 \%$. On the basis of the best results were calculated average delay of other results using different brakes, with additional ballast or changing the nominal pressure in the wheels. Has been then calculated the difference between the results.

The order of actions during the series of measurements were as follows:

$\checkmark$ measurement device calibration,

$\checkmark$ adjusting the pressure in the front wheel,

$\checkmark$ bringing the motorcycle up to the initial value of the measurement speed $\left(V_{1}\right)$,

$\checkmark$ use of the brake/brakes,

$\checkmark$ total deceleration of the motorcycle,

$\checkmark$ copying data from the measuring device to the computer.

All measurements were made on a straight stretch of road, and the process began at the moment of achieving the desired speed. As a result of driving without a gear, have been eliminated additional resistance associated with the inhibition of the engine, so that the measurements are more reliable. 


\section{Experiment results}

The first stage of the research was carried out on a road section (A) of the asphalt surface, undamaged, flat, dry (figure 3).

Tables 3-7 shows the results measured on a section of road (A).

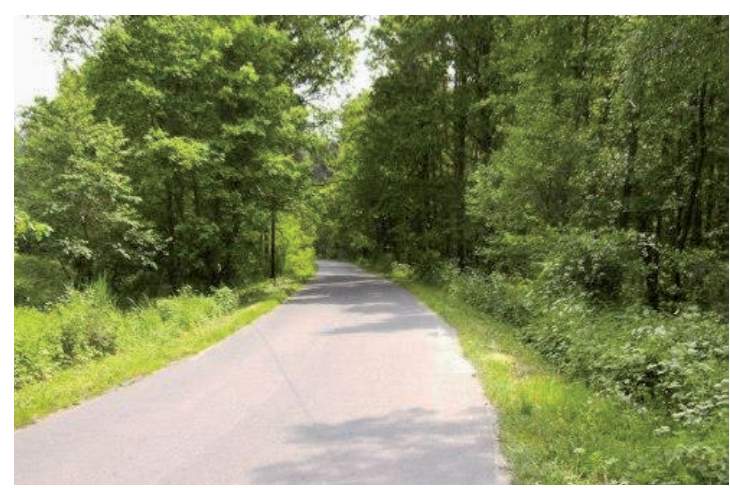

Fig. 2: Section of the road (A).

Table 3: The measurement results of the average total delay on the section (A) $\left[\mathrm{m} / \mathrm{s}^{2}\right]$ - front brake, pressure in the front wheel 2.5 [bar].

\begin{tabular}{|c|c|c|c|}
\cline { 2 - 4 } \multicolumn{1}{c|}{} & \multicolumn{3}{c|}{ Initial speed of measurement } \\
\cline { 2 - 4 } & $\begin{array}{c}30 \\
{[\mathrm{~km} / \mathrm{h}]}\end{array}$ & $\begin{array}{c}40 \\
{[\mathrm{~km} / \mathrm{h}]}\end{array}$ & $\begin{array}{c}50 \\
{[\mathrm{~km} / \mathrm{h}]}\end{array}$ \\
\hline \begin{tabular}{c} 
Only the driver + front brake \\
\hline $\begin{array}{c}\text { The driver and passenger } \\
\text { + front brake }\end{array}$
\end{tabular} & 9,7 & 9,22 & 9,3 \\
\hline Result & $4,3[\%]$ & $9,3[\%]$ & $3,6[\%]$ \\
\hline
\end{tabular}

Table 4: The measurement results of the average total delay on the section $(A)$ in $\left[\mathrm{m} / \mathrm{s}^{2}\right]$ - front and rear brake, pressure in the front wheel 2,5 [bar].

\begin{tabular}{|c|c|c|c|}
\cline { 2 - 4 } \multicolumn{1}{c|}{} & \multicolumn{3}{c|}{ Initial speed of measurement } \\
\cline { 2 - 4 } \multicolumn{1}{c|}{$\begin{array}{c}30 \\
{[\mathrm{~km} / \mathrm{h}]}\end{array}$} & $\begin{array}{c}40 \\
{[\mathrm{~km} / \mathrm{h}]}\end{array}$ & $\begin{array}{c}50 \\
{[\mathrm{~km} / \mathrm{h}]}\end{array}$ \\
\hline $\begin{array}{c}\text { Only the driver + front and } \\
\text { rear brake }\end{array}$ & 8,98 & 8,99 & 9,24 \\
\hline $\begin{array}{c}\text { The driver and passenger } \\
\text { + front and rear brake }\end{array}$ & 7,47 & 8,46 & 8,06 \\
\hline Result & $16,8[\%]$ & $5,9[\%]$ & $12,8[\%]$ \\
\hline
\end{tabular}

The maximum total deceleration have been obtained from all the trials on four different surfaces and shown in Figure 4. The delay of $10,36\left[\mathrm{~m} / \mathrm{s}^{2}\right]$, which is the best result was achieved, interestingly
Table 5: The measurement results of the average total delay on the section $(A)$ in $\left[\mathrm{m} / \mathrm{s}^{2}\right]$ - rear brake, pressure in the front wheel 2,5 [bar].

\begin{tabular}{|c|c|c|c|}
\cline { 2 - 4 } \multicolumn{1}{c|}{} & \multicolumn{3}{c|}{ Initial speed of measurement } \\
\cline { 2 - 4 } & $\begin{array}{c}30 \\
{[\mathrm{~km} / \mathrm{h}]}\end{array}$ & $\begin{array}{c}40 \\
{[\mathrm{~km} / \mathrm{h}]}\end{array}$ & $\begin{array}{c}50 \\
{[\mathrm{~km} / \mathrm{h}]}\end{array}$ \\
\hline $\begin{array}{c}\text { Only the driver + rear brake } \\
\text { The driver and passenger } \\
\text { + rear brake }\end{array}$ & $X$ & 3,59 & $X$ \\
\hline Result & $X$ & 4,39 & $X$ \\
\hline
\end{tabular}

Table 6: The measurement results of the average total delay on the section (A) in $\left[\mathrm{m} / \mathrm{s}^{2}\right]$ - front brake, pressure in the front wheel 2,0 [bar].

\begin{tabular}{|c|c|c|c|}
\cline { 2 - 4 } \multicolumn{1}{c|}{} & \multicolumn{3}{c|}{ Initial speed of measurement } \\
\cline { 2 - 4 } & $\begin{array}{c}30 \\
{[\mathrm{~km} / \mathrm{h}]}\end{array}$ & $\begin{array}{c}40 \\
{[\mathrm{~km} / \mathrm{h}]}\end{array}$ & $\begin{array}{c}50 \\
{[\mathrm{~km} / \mathrm{h}]}\end{array}$ \\
\hline $\begin{array}{c}\text { Only the driver + front brake } \\
\begin{array}{c}\text { The driver and passenger } \\
\text { + front brake }\end{array}\end{array}$ & 9,74 & 9,57 & 9,27 \\
\hline Result & $-0,37$ & 10,12 & 9,99 \\
\hline
\end{tabular}

Table 7: The measurement results of the average total delay on the section $(A)$ in $\left[\mathrm{m} / \mathrm{s}^{2}\right]$ - front brake, pressure in the front wheel 1,5 [bar].

\begin{tabular}{|c|c|c|c|}
\cline { 2 - 4 } \multicolumn{1}{c|}{} & \multicolumn{3}{c|}{ Initial speed of measurement } \\
\cline { 2 - 4 } & $\begin{array}{c}30 \\
{[\mathrm{~km} / \mathrm{h}]}\end{array}$ & $\begin{array}{c}40 \\
{[\mathrm{~km} / \mathrm{h}]}\end{array}$ & $\begin{array}{c}50 \\
{[\mathrm{~km} / \mathrm{h}]}\end{array}$ \\
\hline $\begin{array}{c}\text { Only the driver + front brake } \\
\text { The driver and passenger } \\
\text { + front brake }\end{array}$ & 9,43 & 9,78 & 9,94 \\
\hline Result & 9,56 & 9,79 & 10,19 \\
\hline & $-1,0[\%]$ & $-0,1[\%]$ & $-2,5[\%]$ \\
\hline
\end{tabular}

using only the front brake. Huge importance was very good adhesion of the road surface. For comparison, Figure 5 shows the best result obtained at full load (driver + passenger). Score $10,36\left[\mathrm{~m} / \mathrm{s}^{2}\right]$ is about $11 \%$ better than the value obtained, together with the passenger $\left(9,22\left[\mathrm{~m} / \mathrm{s}^{2}\right]\right)$.

It is often said about the tragic accidents of motorcyclists traveling together with a passenger. How does it happen that the motorcyclist with several years of experience suddenly has an accident, though he had never been in a collision? 
Now, the previously mentioned $11 \%$ may be the best reason, since the braking distance is extended by several decisive meters.

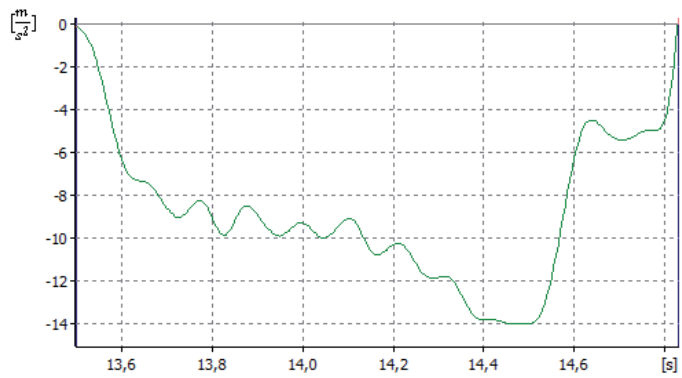

Fig. 4: Chart of braking deceleration - only the driver, front brake, nominal pressure 2,5 [bar].

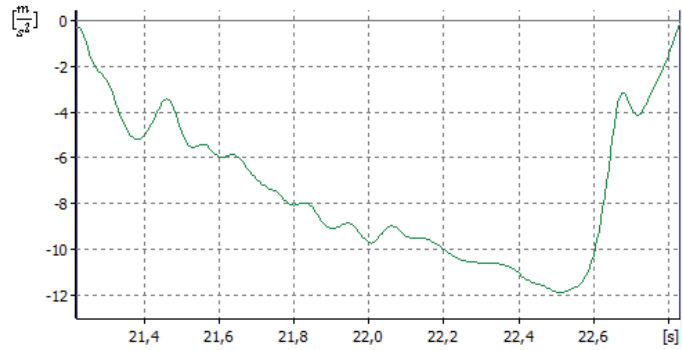

Fig. 5: Chart of braking deceleration - the driver and passenger, front brake, nominal pressure 2,5 [bar].

Average total delay that can be achieved using only the rear brake shown in Figures $6\left(3,54\left[\mathrm{~m} / \mathrm{s}^{2}\right]\right)$ and $7\left(4,41\left[\mathrm{~m} / \mathrm{s}^{2}\right]\right)$.

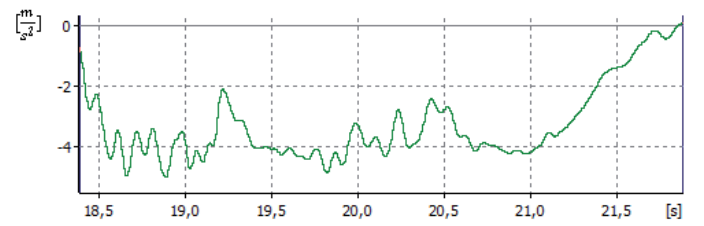

Fig. 6: Chart of braking deceleration - only the driver, rear brake, nominal pressure 2,5 [bar].

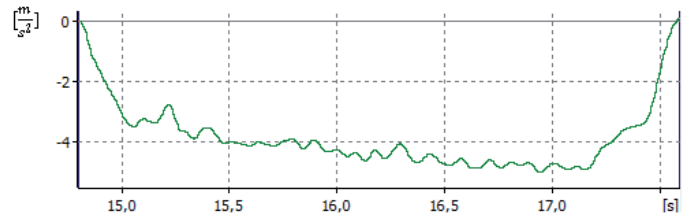

Fig. 6: Chart braking deceleration - the driver + passenger, rear brake, nominal pressure 2,5 [bar].

Inhibiting only the foot brake (rear brake actuated by the foot, located on the right side of the motorcycle) with good adhesion, an important role is played by the mass of the motorcycle with crew. Increasing the weight on the axle on which the brake is used, is obtained by $18,2 \%$ higher total average of delay (Table 5) than without the increased weight. Focusing on the fact that each meter is important, it is better to travel with a passenger while emergency braking only with the rear brake.

The second section of the road on which the measurements were carried out was the road with the gravel surface (figure 8).

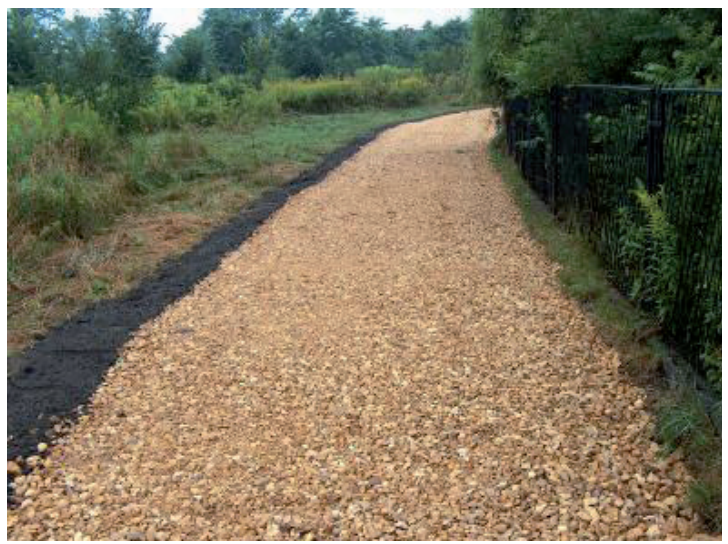

Fig. 8: Section of the road (B).

Due to very difficult test conditions on that surface, the measurements were carried out for the speed of 30 and $40[\mathrm{~km} / \mathrm{h}]$, using the front brake and the nominal pressure occurring in the wheels. The results are summarized in Table 8.

Table 8: The measurement results of the average total delay on the section (B) in $\left[\mathrm{m} / \mathrm{s}^{2}\right]$ - front brake, pressure in the front wheel 2,5 [bar].

\begin{tabular}{|c|c|c|c|}
\cline { 2 - 4 } \multicolumn{1}{c|}{} & \multicolumn{3}{c|}{ Initial speed of measurement } \\
\cline { 2 - 4 } & $\begin{array}{c}30 \\
{[\mathrm{~km} / \mathrm{h}]}\end{array}$ & $\begin{array}{c}40 \\
{[\mathrm{~km} / \mathrm{h}]}\end{array}$ & $\begin{array}{c}50 \\
{[\mathrm{~km} / \mathrm{h}]}\end{array}$ \\
\hline $\begin{array}{c}\text { Only the driver + front brake } \\
\begin{array}{c}\text { The driver and passenger } \\
\text { + front brake }\end{array}\end{array}$ & 4,93 & 4,93 & $X$ \\
\hline Result & $23,5]$ & 3,77 & $X$ \\
\hline
\end{tabular}

In the figures $9\left(\mathrm{am}=5,35\left[\mathrm{~m} / \mathrm{s}^{2}\right]\right)$ and $10(\mathrm{am}=$ $3,33\left[\mathrm{~m} / \mathrm{s}^{2}\right]$ ) are shown waveforms deceleration obtained under different loading values at motorcycle. In both cases was used only the front brake.

Waveform in Figure 9 has a quite turbulent 
$\left[\frac{m}{s^{2}}\right]$

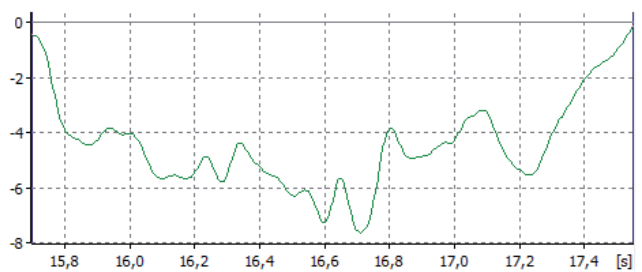

Fig. 9: Chart of braking deceleration - driver, front brake, nominal pressure 2,5 [bar].

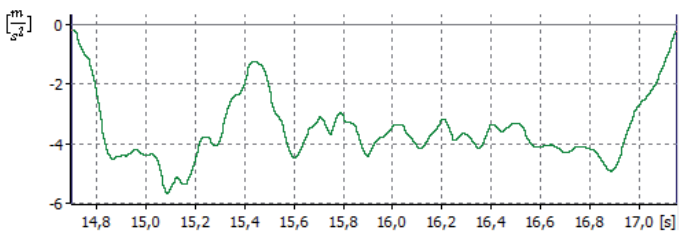

Fig. 10: Chart of braking deceleration - the driver and passenger, front brake, nominal pressure 2,5 [bar].

character compared to Figure 10. The delay is maintained between $4-7\left[\mathrm{~m} / \mathrm{s}^{2}\right]$, and the total average delay is up to $5,35\left[\mathrm{~m} / \mathrm{s}^{2}\right]$. On a more balanced process shown in Figure 10 had an impact greater stability of the motorcycle resulting from a larger load. The percentage difference between the results obtained (Table 8 ) is up 23,5\% for the initial speed of $30[\mathrm{~km} / \mathrm{h}]$ and $15,3 \%$ for the initial speed of $40[\mathrm{~km} / \mathrm{h}]$.

Better sense of front wheel slippage while driving without additional load enables immediate correction of the braking force by decreasing or increasing the pressure on the brake lever. As a result, the tire does not slip.

The third section, on which the measurements were carried out was the asphalt road with flat, dry and smooth surface (figure 11). Comparing the road surface (A) and ( $\mathrm{C} 1)$, the section (A) has a surface having an apparent porosity (coefficient of adhesion approx. 1.0), while the section ( $\mathrm{C} 1$ ) has a smooth surface (coefficient of adhesion approx. 0.7).

In Tables 9 and 10 summarizes the results measured on a section of road (C1).

In the figures $12\left(\mathrm{am}=7,40\left[\mathrm{~m} / \mathrm{s}^{2}\right]\right)$ and $13(\mathrm{am}=$ $6,55\left[\mathrm{~m} / \mathrm{s}^{2}\right]$ )are shown an example waveforms obtained braking deceleration, with different way of inhibiting the motorcycle - the front brake or the front and rear. When using only the front brake achieved waveform of braking deceleration is more turbulent in nature, than using both brakes front and rear. The additional use of the second brake (in

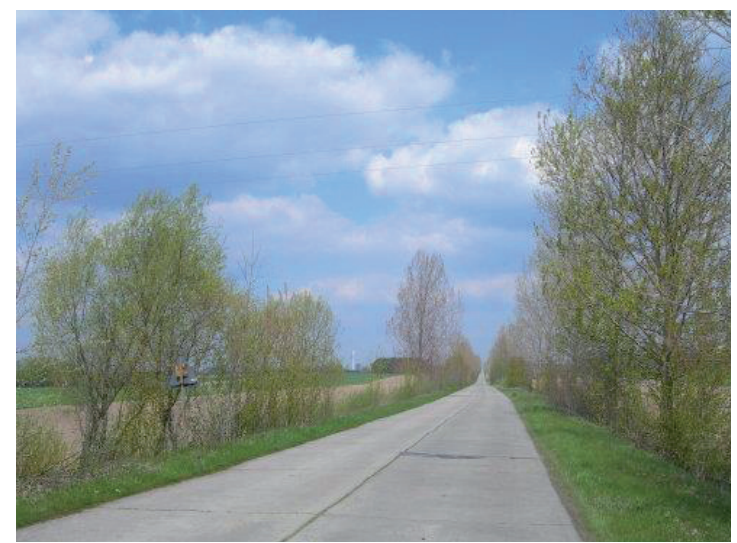

Fig. 11: Section of the road (C1).

Table 9: The measurement results of the average total delay on the section (C1) in $\left[\mathrm{m} / \mathrm{s}^{2}\right]$ - front brake, pressure in the front wheel 2,5 [bar].

\begin{tabular}{|c|c|c|c|}
\cline { 2 - 4 } \multicolumn{1}{c|}{} & \multicolumn{3}{c|}{ Initial speed of measurement } \\
\cline { 2 - 4 } \multicolumn{1}{c|}{} & $\begin{array}{c}30 \\
{[\mathrm{~km} / \mathrm{h}]}\end{array}$ & $\begin{array}{c}40 \\
{[\mathrm{~km} / \mathrm{h}]}\end{array}$ & $\begin{array}{c}50 \\
{[\mathrm{~km} / \mathrm{h}]}\end{array}$ \\
\hline $\begin{array}{c}\text { Only the driver + front brake } \\
\text { The driver and passenger } \\
\text { + front brake }\end{array}$ & 7,74 & 7,23 & 6,88 \\
\hline Result & 6,99 & 7,70 & 7,53 \\
\hline
\end{tabular}

Table 10: The measurement results of the average total delay on the section (C1) in $\left[\mathrm{m} / \mathrm{s}^{2}\right]$ - front and rear brake, pressure in the front wheel 2,5 [bar].

\begin{tabular}{|c|c|c|c|}
\cline { 2 - 4 } \multicolumn{1}{c|}{} & \multicolumn{3}{c|}{ Initial speed of measurement } \\
\cline { 2 - 4 } & $\begin{array}{c}30 \\
{[\mathrm{~km} / \mathrm{h}]}\end{array}$ & $\begin{array}{c}40 \\
{[\mathrm{~km} / \mathrm{h}]}\end{array}$ & $\begin{array}{c}50 \\
{[\mathrm{~km} / \mathrm{h}]}\end{array}$ \\
\hline Only the driver + front brake & 7,50 & 7,10 & 7,22 \\
\hline $\begin{array}{c}\text { The driver and passenger } \\
\text { + front brake }\end{array}$ & 7,39 & 7,52 & 6,93 \\
\hline Result & $1,5[\%]$ & $-5,9[\%]$ & $4,0[\%]$ \\
\hline
\end{tabular}

addition to the brake - the front) results in a more stable braking process but may not always moves to a better result of the total average delay.

Motorcyclist under the stress caused by sudden braking is not able to precisely control the two brakes simultaneously. Most often it looks like that, during the use of the second brake, the first is gently, "absolved". Properly trained and experienced drivers definitely prefer to use only one brake, which is the front brake. 
$\left[\frac{\mathrm{m}}{\mathrm{s}^{2}}\right]$

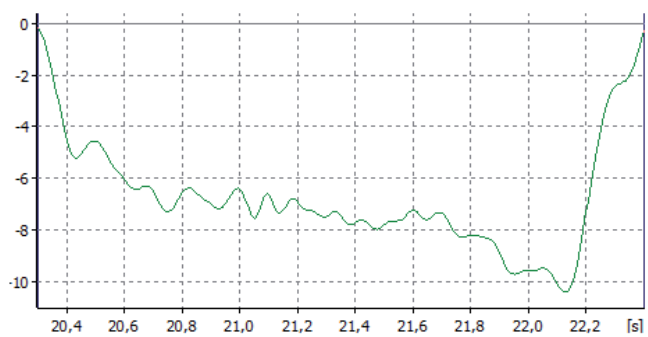

Fig. 12: Chart of braking deceleration - the driver and passenger, front brake, nominal pressure 2,5 [bar].

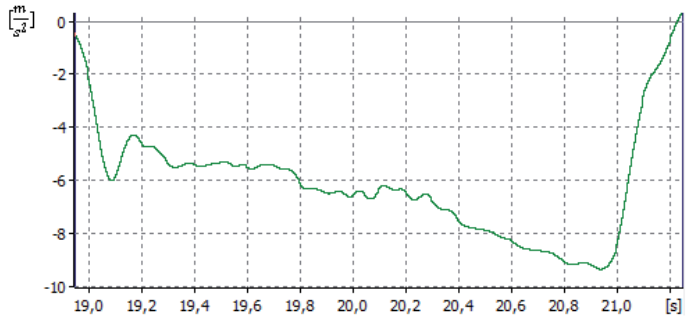

Fig. 13: Chart of braking deceleration - the driver and passenger, front and rear brake, nominal pressure 2,5 [bar].

The last phase of measurements was made on the road $(\mathrm{C} 1)$ but with a wet surface $(\mathrm{C} 2)$.

Values of average total delays are very small, what was the result of the smooth and wet surface. The results are only slightly better than the average values of braking on gravel roads. It is noteworthy that the value of delays set out in this stage of research, often are found in everyday driving - the bad weather conditions caused by falling rain, and poor quality of the road surface.

Tables 11 and 12 summarize the results obtained for the road (C2).

Table 11: The measurement results of the average total delay on the section (C2) in $\left[\mathrm{m} / \mathrm{s}^{2}\right]$ - front brake, pressure in the front wheel 2,5 [bar].

\begin{tabular}{|c|c|c|c|}
\cline { 2 - 4 } \multicolumn{1}{c|}{} & \multicolumn{3}{c|}{ Initial speed of measurement } \\
\cline { 2 - 4 } \multicolumn{1}{c|}{$\begin{array}{c}30 \\
{[\mathrm{~km} / \mathrm{h}]}\end{array}$} & $\begin{array}{c}40 \\
{[\mathrm{~km} / \mathrm{h}]}\end{array}$ & $\begin{array}{c}50 \\
{[\mathrm{~km} / \mathrm{h}]}\end{array}$ \\
\hline $\begin{array}{c}\text { Only the driver + front brake } \\
\text { The driver and passenger } \\
+ \text { +front brake }\end{array}$ & 5,17 & 5,22 & 5,38 \\
\hline Result & $-9,1[\%]$ & $-15[\%]$ & $-10[\%]$ \\
\hline
\end{tabular}

Table 12: The measurement results of the average total delay on the section (C2) in $\left[\mathrm{m} / \mathrm{s}^{2}\right]$ - front and rear brake, pressure in the front wheel 2,5 [bar].

\begin{tabular}{|c|c|c|c|}
\cline { 2 - 4 } \multicolumn{1}{c|}{} & \multicolumn{3}{c|}{ Initial speed of measurement } \\
\cline { 2 - 4 } \multicolumn{1}{c|}{} & $\begin{array}{c}30 \\
{[\mathrm{~km} / \mathrm{h}]}\end{array}$ & $\begin{array}{c}40 \\
{[\mathrm{~km} / \mathrm{h}]}\end{array}$ & $\begin{array}{c}50 \\
{[\mathrm{~km} / \mathrm{h}]}\end{array}$ \\
\hline $\begin{array}{c}\text { Only the driver + front brake } \\
\text { The driver and passenger } \\
\text { + front brake }\end{array}$ & 6,33 & 6,51 & 6,31 \\
\hline Result & 7,32 & 6,31 & 6,21 \\
\hline
\end{tabular}

In the case of measurements on a wet surface large role is played by an additional use of the rear brake. For researches conducted in dry conditions, the use of an additional rear brake caused getting worse results. On Figure $14\left(\mathrm{am}=5,06\left[\mathrm{~m} / \mathrm{s}^{2}\right]\right)$ waveform is more stable than in Figure $15\left(\mathrm{am}=7,35\left[\mathrm{~m} / \mathrm{s}^{2}\right]\right)$. This does not mean achieving better results. In the case of braking only by the front brake, deceleration fluctuates within 4-6 $\left[\mathrm{m} / \mathrm{s}^{2}\right]$. While in the case of use in addition the rear brake, deceleration increases to $6-8\left[\mathrm{~m} / \mathrm{s}^{2}\right]$, improving the total average deceleration of more than $2\left[\mathrm{~m} / \mathrm{s}^{2}\right]$ in relation to trials involving only the front brake. Can be seen here that in the wet surface it is worth to use an additional brake, which complements the basic brake.

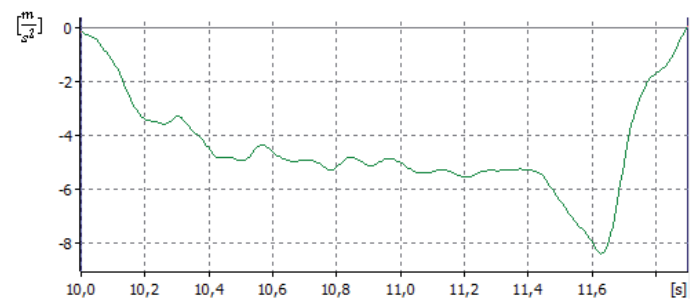

Fig. 14: Chart of braking deceleration - the driver and passenger, front brake, nominal pressure 2,5 [bar].

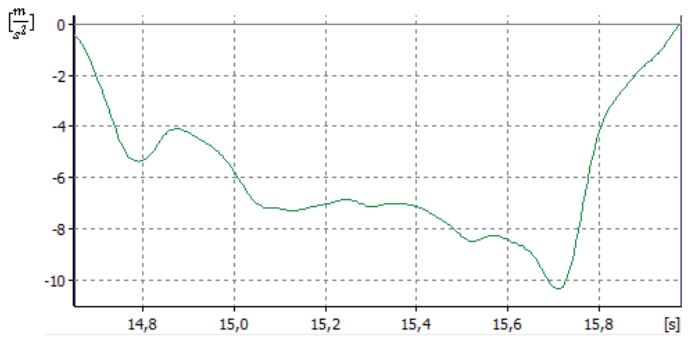

Fig. 15: Chart of braking deceleration - the driver and passenger, front and rear brake, nominal pressure 2,5 [bar]. 
In both figures it is worth noting a significant increase in braking power in the final phase of the whole process. It is the result of a sharp braking at low speed. Such a significant increase in force value is not possible in the initial stage of inhibiting even at the asphalt road with the largest coefficient of adhesion. This is because, at the beginning of inhibiting motorcyclist is not able to assess what the real adhesion is and is forced with moderate force to grab the front brake levers. The consequence of a sharp initial braking on wet surfaces could lead to a slippage of the front wheel, which could be a consequence of an accident. The obtained percentage difference between the averages results of the total braking deceleration is in favor of trials in which were used both brakes. Result 23,2\% requires no additional comment.

It is worth also to pay attention to the comparison of results obtained during the measurement in the wet, with an additional reduced pressure in the front wheel - tables 13 and 14.

Table 13: The measurement results of the average total delay on the section (C2) in $\left[\mathrm{m} / \mathrm{s}^{2}\right]$ - front brake, pressure in the front wheel 2,0 [bar].

\begin{tabular}{|c|c|c|c|}
\hline & \multicolumn{3}{|c|}{ Initial speed of measurement } \\
\hline & $\begin{array}{c}30 \\
{[\mathrm{~km} / \mathrm{h}]}\end{array}$ & $\begin{array}{c}40 \\
{[\mathrm{~km} / \mathrm{h}]}\end{array}$ & $\begin{array}{c}50 \\
{[\mathrm{~km} / \mathrm{h}]}\end{array}$ \\
\hline Only the driver + front brake & 5,27 & 5,14 & 5,36 \\
\hline $\begin{array}{l}\text { The driver and passenger } \\
+ \text { front brake }\end{array}$ & 5,81 & 5,45 & 5,32 \\
\hline Result & $-9,3[\%]$ & $-5,7[\%]$ & $0,8[\%]$ \\
\hline
\end{tabular}

Table 14: The measurement results of the average total delay on the section (C2) in $\left[\mathrm{m} / \mathrm{s}^{2}\right]$ - Front brake pressure in the front wheel 1,5 [bar]

\begin{tabular}{|c|c|c|c|}
\cline { 2 - 4 } \multicolumn{1}{c|}{} & \multicolumn{3}{c|}{ Initial speed of measurement } \\
\cline { 2 - 4 } \multicolumn{1}{c|}{} & $\begin{array}{c}30 \\
{[\mathrm{~km} / \mathrm{h}]}\end{array}$ & $\begin{array}{c}40 \\
{[\mathrm{~km} / \mathrm{h}]}\end{array}$ & $\begin{array}{c}50 \\
{[\mathrm{~km} / \mathrm{h}]}\end{array}$ \\
\hline \begin{tabular}{c} 
Only the driver + front brake \\
\hline $\begin{array}{c}\text { The driver and passenger } \\
+ \text { front brake }\end{array}$
\end{tabular} & 5,33 & 5,19 & 5,51 \\
\hline Result & $3,9[\%]$ & $-1[\%]$ & $-8,9[\%]$ \\
\hline
\end{tabular}

On Figures $16\left(\mathrm{am}=6,13\left[\mathrm{~m} / \mathrm{s}^{2}\right]\right)$ and $17(\mathrm{am}=$ $\left.4,45\left[\mathrm{~m} / \mathrm{s}^{2}\right]\right)$ are shown obtained exemplary waveforms of deceleration under a reduced $\left[\frac{\mathrm{m}}{3^{3}}\right]$

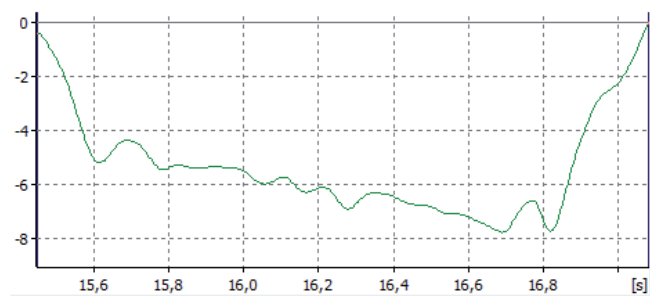

Fig. 16: Chart of braking deceleration - the driver and passenger, front brake, nominal pressure 2,0 [bar].

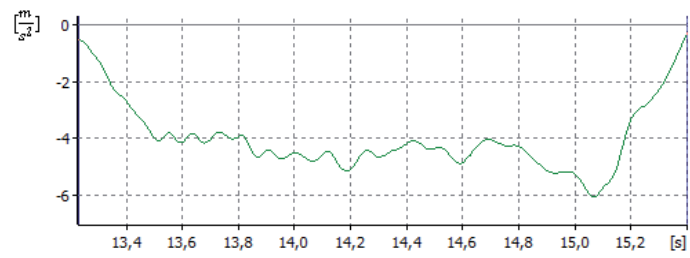

Fig. 17: Chart of braking deceleration - the driver and passenger, front brake, nominal pressure 1,5 [bar].

pressure in the front wheel.

Figure 17 shows that the curve with the chart in the middle of range clearly "writhe". This behaviour is caused by periodic slippage of the front wheel. As a result of the braking, with a substantial reduction in pressure, the tire is deformed (under the force the tire adheres with greater surface to the wet road). The obtained average value of deceleration is considerably greater in the case shown in Figure 16 because the pressure in the tire is closer to the nominal value, allowing the tire to behave almost like with the proper pressure. The obtained difference between the presented trials is up $27,4 \%$.

\section{Conclusions}

On the world's roads every year is recorded an increase in the number of vehicles. This has adverse effects, for example in the form of a negative impact on the environment or the increased number of road accidents. All over the world work is underway in order to limit or prevent any type of negative effects of this state of affairs $[3-5,8,12,16,20]$.

By analyzing traffic accidents involving motorcyclists can be seen that some of them could have been avoided if they were attended by more experienced drivers.

The braking system of motorcycle and its construction must deal effectively with the existing conflict - between the desire to possibly the most 
effective braking and driving stability. Two factors affecting the maintenance of the balance by riding a motorcycle are the force of inertia and the gyroscopic forces generated by spinning wheels. In maintaining the balance help spinning wheels of motorcycle. They generate a stabilizing gyro force which counteracts the movement of the wheel in a horizontal or vertical deviation. If this stabilizing is interrupted by brief, excessively heavy braking, with the occurrence of tendency to blocking of one wheel, may result in loss stability and usually leads to the inclination of the vehicle. Since the occurrence of skidding over-braked of the front wheel, the component of the centrifugal force decreases, which favors further tilting of the vehicle. Prevent to this tendency can only occurrence of strong lateral force or lateral adhesion, which cannot be achieved even when the wheel is not completely inhibited. This is one of the most common reasons for overturning the motorcyclists [7, 10, 11, 17-19].

As in the case of a passenger car, the surface of contact of the tire with the road must move all the forces associated with delay of inhibiting the motorcycle. The main difference is that the centre of mass for the motorcycle is in the plane of the wheels. The size of the normal force acting on the point of contact patch is dependent on the distance of the centre of mass to the front and rear axles. Unfortunately, in the case of a motorcycle, the centre of mass relative to the wheel base is twice higher than in the case of a passenger car. The result is a situation arising in which the force resulting from a delay applied to the centre of mass of the motorcycle, causes additional burden on the front wheel and unburden on the rear wheel at the same time. Therefore, in case of emergency braking, the motorcycle tends to detach the rear wheel from the road surface (in particular for one person driving). The impact of this phenomenon has also the size and kind of the tires [7, 10, 11, 17-19].

The most important conclusions from the conducted research include:

$\checkmark$ the maximum average total deceleration which were obtained in all the tests carried out on four different surfaces was 10,19 [m/s $\left.\mathrm{s}^{2}\right]\left(V_{1}=50[\mathrm{~km} / \mathrm{h}]\right.$, road $(A)$, driver and passenger, front brake, pressure in the front wheel 1,5 [bar]);

$\checkmark$ the minimum average total deceleration which were obtained in all the tests carried out on four different surfaces was 3,77 $\left[\mathrm{m} / \mathrm{s}^{2}\right]\left(V_{1}=40[\mathrm{~km} / \mathrm{h}]\right.$, road (B), driver and passenger, front brake, pressure in the front wheel 2,5 [bar]);

$\checkmark$ on the road section (A), at a nominal pressure of the front wheel of 2,5 [bar], the measurement results obtained while driving only by the driver were higher for each initial speed $(30,40,50[\mathrm{~km} / \mathrm{h}]$ as compared to driving with an additional passenger. The only surprise was the result achieved using only the rear brake. Here, the higher the score recorded for driving involving passenger (due to weighted down the rear axle);

$\checkmark$ reducing the pressure in the front wheel on the section (A), better results were seen while driving with passenger (up to $7,2 \%$ in favor of the driving with passenger);

$\checkmark$ for the road (B) better results were noted for driving by the driver himself than with a passenger-15,3\% for the initial speed $40[\mathrm{~km} / \mathrm{h}]$, and even $23,5 \%$ for the speed of $30[\mathrm{~km} / \mathrm{h}]$. This result reflects improve the dosing of front brake on rough road when the motorcycle is not burdened. In such a situation, the motorcyclist can better balance the motorcycle, which turns out to be extremely important in driving on rough roads. Eventually, such behavior of motorcyclists affects a better result;

$\checkmark$ for the road (C1), all obtained averages from the measurements are within the range 6,88-7,74 $\left[\mathrm{m} / \mathrm{s}^{2}\right]$. Very small variations indicates the little impact of the load to motorcycle, as well as the selection of the applied brake for a smooth asphalt surface.;

$\checkmark$ on the road section (C2), average total braking deceleration is higher at reduced pressure in the front wheel regardless of whether the user uses the front brake, or the front and rear brake simultaneously. The only anomaly that has been observed is its lower value while the trial is initiated with initial speed $30[\mathrm{~km} / \mathrm{h}]$. The difference was 13,5\% at the expense of examined the lighter variant.

\section{Acknowledgements}

Scientific work financed from the funds of the Ministry of Science and Higher Education.

\section{References and Notes}

[1] Chalecki, M. (2006). Conventional and electronic brake systems. Wydawnictwa Komunikacji i Łączności. Warszawa.

[2] Czech, P., Łazarz, B., Madej, H. (2010). The influence of the pressure in tyres and the load of the car on the delay and the braking distance of a motor-car without ABS system. Scientific Journal of Silesian University of Technology. Series Transport. Vol. 69, p. 21-28. ISSN: 0209-3324. 
[3] Grega, R., Homišin, J., Kaššay, P., Krajňák, J. (2011). The analyse of vibrations after changing shaft coupling in drive belt conveyer. Scientific Journal of Silesian University of Technology. Series Transport. Vol. 72, p. 23-31. ISSN: 0209-3324.

[4] Harachová, D., Medvecká-Beňová, S. (2013). Applying the modutarity principle in design of drive systems in mechanotherapeutic devices. Grant Journal. Vol. 2(2), p. 80-82 ISSN 1805-062X.

[5] Homišin, J. (2008). Tuning torsionally vibrating mechanical systems using pneumatic couplings: a compendium of performance research. ATH, Bielsko-Biała.

[6] Hough, D.L. (2004). Perfect motorcyclist. Wydawnictwo Buk Rower. Warszawa.

[7] Leiter, R. (1998). Braking cars and motorcycles. Wydawnictwo Komunikacji i Łączności. Warszawa.

[8] Medvecká-Beňová, S., Vojtková, J. (2013). Analysis of asymmetric tooth stiffness in eccentric elliptical gearing. Technológ. Vol. 5(4), p. 247-249. ISSN: 1337-8996.

[9] Miatluk, M., Kamiński, Z. (2005). Braking systems of vehicles: calculations. Wydawnictwo Politechniki Białostockiej. Białystok.

[10] Prochowski, L. (2005). Mechanics of movement. Wydawnictwo komunikacji i Łączności. Warszawa.

[11] Prochowski, L., Unarski, J., Wach, W., Wicher, W. (2008). Basics accident reconstruction. Wydawnictwa Naukowo-Techniczne. Warszawa.

[12] Puškár, M., Bigoš, P., Puškárová, P. (2012). Accurate measurements of output characteristics and detonations of motorbike high-speed racing engine and their optimization at actual atmospheric conditions and combusted mixture composition. Measurement. Vol. 45, p. 1067-1076, ISSN: 0263-2241.

[13] Reński, A. (1997). Construction of car: braking and steering and suspension. Oficyna Wydawnicza Politechniki Warszawskiej. Warszawa.

[14] Siłka, W. (2002). Theory of a moving car. Wydawnictwa Naukowo-Techniczne. Warszawa.

[15] Skrzypczyk, P., Kałuża, R., Czech, P. (2015). Braking process of enduro and highway-tourist motorbikes. Scientific Journal of Silesian University of Technology. Series Transport. Vol. 87, p. 49-62. ISSN: 0209-3324.

[16] Urbanský, M., Homišin, J., Krajňák, J. (2011). Analysis of the causes of gaseous medium pressure changes in compression space of pneumatic coupling. Transactions of the Universities of Košice. Vol. 2, p. 35-40. ISSN: 1335-2334

[17] Wicher, J. (2004). Safety cars and traffic. Wydawnictwa Komunikacji i Łączności. Warszawa.

[18] Wierciński, J. (red.). (1985). Road accidents - elements of technical analysis and evaluation. Wydawnictwa Komunikacji i Łączności. Warszawa.
[19] Wierciński, J., Reza, A. (red.). (2011). Road accidents. Vademecum of court expert. Wydawnictwo Instytutu Ekspertyz Sądowych. Kraków.

[20] Zuber, N., Bajrić, R., Šostakov, R. (2014). Gearbox faults identification using vibration signal analysis and artificial intelligence methods. Eksploatacja i Niezawodność - Maintenance And Reliability. Vol. 16(1), p. 61-35. ISSN: 1507-2711.

\section{Biographical notes}

Doctor habilitated Piotr Czech, Eng., is employed as a professor of the Silesian University of Technology, Faculty of Transport, Department of Automotive Vehicles Construction. He deals with issues connected with vibroacoustics of machines, diagnosing combustion engines and gearboxes, automotive mechatronics. In his scientific work, he deals with using the artificial intelligence methods and signal processing methods in diagnosing components of power transmission systems. He is the winner of the competition for the Prize of President of the Council of Ministers and for Fiat Prize.

Błażej Szyma, Ing., is a graduate of Faculty of Transport, Silesian University of Technology, Poland.

Michał Juzek, Ing., is a graduate of Faculty of Transport, Silesian University of Technology, Poland.

Robert Kałuża, Ing., is a graduate of Faculty of Transport, Silesian University of Technology, Poland. 